\author{
Cadernos de \\ ESTUdOS LINGüĺsticOS - (54.2), Campinas, Jul./Dez. 2012
}

\title{
OS ESTRANGEIRISMOS E OS EMPRÉSTIMOS NO PORTUGUÊS FALADO EM MOÇAMBIQUE
}

\author{
ALEXANDRE ANTONIO TIMBANE*
}

\begin{abstract}
RESUMO
Este trabalho é uma reflexão sobre a situação do português em Moçambique, especialmente na questão de "variação e mudança linguística" que se processa através de estrangeirismos e empréstimos. O português convive com mais de vinte línguas bantu e duas asiáticas, o que permite contato entre elas. O português é língua oficial e não é materna para a maioria dos moçambicanos. Assim, pretendemos identificar e apresentar os estrangeirismos e empréstimos fenómeno que se verifica mais nos mídias. Descreveremos a integração dessas "novas" palavras no português moçambicano bem como o seu valor semântico. O corpus é composto por 27 cartas de opinião recolhidas no jornal "Notícias", em 2010 e 2011, o qual foi inserido no programa Lexico-3. Da pesquisa, se concluiu que a maior parte dos empréstimos e estrangeirismos provém das línguas bantu bem como do inglês. A integração dessas palavras segue as regras gramaticais do português, havendo dificuldades em muitos casos, na transformação da ortografia das línguas bantu para português. Os estrangeirismos ainda são alvos de preconceito, principalmente no meio escolar mas as mudanças linguísticas são fenómenos naturais das línguas e ninguém os pode impedir de existir.
\end{abstract}

Palavras chave: estrangeirismos; empréstimos; Português moçambicano.

\begin{abstract}
This work is a reflection of Portuguese situation in Mozambique, specially on the matter of linguistic changes and variation, which is processed through foreignism and borrowing. The Portuguese language is surrounded by more than twenty Bantu and two Asiatic languages. Portuguese is the official language and is not the first language (a mother tongue or a native) for the majority of Mozambicans. Thus, in this work we identified and described the foreignism and borrowing language phenomenon found in most media. Also, we described the integration of these new words into Mozambican Portuguese and their semantic value. The corpus consisted of 27 letters of opinion gathered in the newspaper " Jornal Notícias" in the period of 2010 to 2011, which was inserted into the Lexico-3 program. From research, it appears that most of the loans and foreign words come from the Bantu languages as well as English. The integration of these words follows the rules of Portuguese grammar. The difficulties observed in many cases are associated with the transformation of the spelling of the Bantu languages into Portuguese. The foreigners are still targets of preconception, mainly in schools but linguistic changes are natural phenomena of languages and one can stop.
\end{abstract}

Key-words: foreignisms; borrowings; Mozambican portuguese.

*UNESP, São Paulo (SP), Brasil. <alextimbana@hotmail.com> 
TIMBANE - Os estrangeirismos e os empréstimos...

\section{INTRODUÇÃO}

Moçambique é um país multilíngue. O português é a língua oficial, não sendo materna para a maioria da população. O país possui 38,7\% (Censo 2007) da população escolarizada. A maioria da população $(71,4 \%)$ vive nas zonas rurais e usa as línguas bantu na comunicação cotidiana. O português é falado especialmente por pessoas escolarizadas ou por aquelas que vivem nas capitais das províncias, em sua maioria. $\mathrm{O}$ português tem a estatuto político mais privilegiado porque $\mathrm{o}$ artigo $9^{\circ}$ e $10^{\circ}$, da Constituição da República de Moçambique (de 2004) determina o português como oficial. Para além das línguas bantu também se fala duas línguas asiáticas (urdu e o gujarati) graças à comunidade asiática radicada em Moçambique. Num país multilingue como é o caso de Moçambique acontece o contato linguístico que de certo modo pode provocar fenómenos de variação e mudanças linguísticas.

O tema que vamos desenvolver Os estrangeirismos e empréstimos no português falado em Moçambique pode até parecer banal. Mas entendemos que os estrangeirismos diferem de uma região para outra daí a necessidade de tratar este fenómeno linguístico moçambicano. As evidências mostram que os empréstimos e os estrangeirismos do Brasil, por exemplo, são diferentes de Português e muito menos de Angola ou Moçambique. Mostraremos ao longo deste trabalho, o léxico que ilustra o que acabamos de afirmar. Mostrar sempre que possível, exemplos de empréstimos e estrangeirismos moçambicanismos como forma de ligar a fundamentação teórica da prática.

Este trabalho visa discutir e descrever os fenómenos de empréstimos e estrangeirismos no português falado em Moçambique e sustentar o pressuposto de que as línguas mudam com o tempo e que o português não seria excessão. Visa também, mostrar a necessidade do uso do dicionários de moçambicanismos em sala de aulas uma vez que estes fenómenos ocorrem na literatura.

\section{OS ESTRANGEIRISMOS E OS EMPRÉSTIMOS}

As línguas evoluem com o tempo. Os contextos sociais, económicos, políticos e culturais muitas vezes influenciam nas mudanças e variações linguísticas. Num primeiro passo, isso afecta o léxico das línguas. As mudanças podem afectar os aspectos fonéticos, lexicais, morfo-sintáticos e semânticos. As mudanças podem provir de neologismos, estrangeirismos e empréstimos. O estudo destes três conceitos é vasto daí que precisa de um espaço próprio. Assim, delimitamos o nosso estudo nos empréstimos e empréstimos, deixando os neologismos para um futuro trabalho.

\subsection{Os estrangeirismos: conceitos e debates}

A noção de estrangeirismos tem sido tema de debate entre linguistas. Opiniões divergem quanto à definição conceitos-chave. Mas na verdade, está-se falando do 
mesmo fenómeno linguístico. ROMAINE (1995, p.51) designa por interferência e outros linguistas denominam "anglicismos, anglo-americanismos, barbarismos" (SEQUEIRA, 1962), africanismos (BONVINI, 2004, p.53), xenismo (GUILBERT, 1975, p.92), galicismos, latinismos, italianismos, perigrinismos, estrangeirices, britanismos entre outras designações.

Segundo FREITAS, RAMILO e SOALHEIRO (2005, p.37) estrangeirismos "são palavras provenientes de línguas estrangeiras ${ }^{1}$ que não estão integradas no léxico do português, sendo empregues na nossa língua”. Segundo os mesmos autores, empréstimo é usado para designar não só as palavras estrangeiras mas também o processo de passagem de uma língua para a outra.

Estrangeirismo é o emprego, na língua de uma comunidade, de elementos oriundos de outras línguas. Nota-se também que GARCEZ e ZILLES (2001, p.15), PERINI (2004, p.11-16) BONVINI (2004, p.53-59) não fazem distinção clara entre estrangeirismos e empréstimos. Outro linguista que merece ser citado, nesta procura de conceitos, é RAJAGOPALAN (2004, p.11-38) que evita claramente os conceitos aqui apresentados. O autor usa o termo "invasão linguística" e em alguma parte ainda utiliza a palavra "chauvinismo" . Esta última definição é um pouco preconceituosa segundo o nosso entendimento. É interessante a sua colocação porque evita de qualquer jeito o uso das palavras: estrangeirismos, empréstimos ou neologismos embora falando destes mesmos fenómenos. Mas como queremos, de fato, ficarmos claros nesta questão dos conceitos apresentamos, as definições de GONÇALVES, FERREIRA e CUNHA ( 2011, p.2-4) que nos parecem mais específicos e claros na nossa opinião:

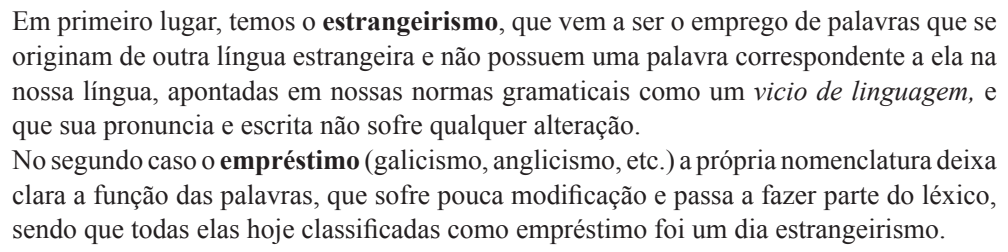

Sendo assim, entendemos por estrangeirismo uma palavra de uma língua "A" que é usada língua "B" em que pelo menos uma das suas características de origem não foram desvirtuadas, nomeadamente a nível fonológico, a nível semântico e a nível ortográfico. No caso de países plurilíngues, (como é o caso de Moçambique) o estrangeirismo pode vir de várias línguas existentes no território. É comum que os traços dessas línguas possam se manifestar no português, nem que seja em uma percentagem menor. Peguemos, então alguns exemplos ${ }^{3}$ de estrangeirismos provenientes da língua xichangana para o português em Moçambique:

${ }^{1}$ Não entendamos estrangeiro como algo que está fora do país. Referimo-nos algo que está fora da língua. Por que em Moçambique há estrangeirismos entre línguas bantu faladas no espaço geográfico de Moçambique. Por exemplo, no xichangana há empréstimos de xitswa, gitonga.

${ }^{2}$ Chauvinismo ou chovinismo (do francês chauvinisme) é o termo dado a todo tipo de opinião exacerbada, tendenciosa, ou agressiva em favor de um país, grupo ou idéia.

${ }^{3}$ Exemplos extraidos do "Minidicionário de moçambicanismos." 
TIMBANE - Os estrangeirismos e os empréstimos...

Matorritorri: doce feito de coco e açúcar com forma rectangular, quadrangular ou losangular. (p.156)

Tchovaxitaduma: veículo usado para o transporte de carga, constituído por uma carroça, com duas rodas, que é puxada pelo homem.(p.222)

Matapa: preparação culinária feita a partir de folhas de mandioca com amendoim. (p.154)

Matequenha: bicho de pé, nigua, pequeno insecto semelhante a pulga, próprio de regiões quentes, cuja fêmea põe ovos na pele de homens e de outros animais. (p.155)

Timbila: xilofone (p.224)

Khanimambo: obrigado (p.125)

Tontonton: aguardente de fabrico caseiro (p.226)

Cada comunidade linguística falante de português tem os seus empréstimos e estrangeirismos. Este fenómeno resulta no contacto que cada grupo linguístico tem com outras línguas ao seu redor. Vejamos, outros exemplos que ocorrem no português brasileiro: pendrive, delivery, cheeseburguer, show, shopping, $H D^{4}$ (provém do inglês hard disk), bullying, short, time, dread (provém do inglês dreadlocks), penalty, placard (provém do francês placar), slogan e reality-show.

\subsubsection{Processos de integração de estrangeirismos}

Os estrangeirismos logo que entram na língua, alguns conseguem manter suas características de proveniência mas outras mudam transformando-se em empréstimos. Vejamos as fases dessas transformações. A transformação lexical segue três fases:

\footnotetext{
Na primeira fase, há adaptação fonética imediata, adaptação morfo-sintática imediata. Monossemia: manutenção de um dos significados da língua de origem, grafia da língua de origem e por fim hesitação nos tipos gráficos. Na segunda fase, há aprofundamento da adaptação fonética e morfo-sintática, possibilidade de formação de novas palavras por composição e prefixação tendo como base estrangeirismo, aparecimento de formas gráficas em alternativa às da língua de origem. Finalmente, na terceira fase, há estabilização fonológica: fixação do acento. Plena integração morfo-sintática: fixação do género e das formas de singular e plural. integração no sistema morfológico da língua: possibilidade de derivação, polissemia: tendência para a extensão do significado de forma original. (FREITAS, RAMILO E SOALHEIRO, 2005, p.37-49)
}

É importante sublinhar que as transformações fonéticas e ortográficas fazem com que haja passagem de estrangeirismo para empréstimo. Passemos agora ao conceito de empréstimo.

\footnotetext{
${ }^{4}$ Também significa "high definition" (alta definição).
} 


\title{
1.2. Desconfigurando a noção empréstimos
}

Alguns analistas da língua, costumam dar pouca importância à diferença dos conceitos entre empréstimos e estrangeirismos. Neste trabalho, preferimos demarcar com mais visibilidade o nosso interesse, indicando o que entendemos por empréstimos linguísticos. Entende-se neste contexto por empréstimo a transformação de uma palavra estrangeira para se adaptar à realidade de uma nova língua. Assim,

\begin{abstract}
Se adotarmos star, logo teremos estartar (e todas as suas flexões), pois nossa língua não tem sílabas como st-, que imediatamente se tornam est-. Veja bem: não só acrescenta uma vogal, mas ela será um $\mathbf{e}-$ em algumas regiões regiões, um i, por razões de pronúncia, não de estrutura - que é nossa vogal protética e epentética. A forma nunca será startar, nem ostartar ou ustartar, nem estarter ou estartir, nem printer ou printir, nem atacher ou atachir etc, etc, etc. Isso é que é aportuguesar, e não providenciar uma ortografia para a palavra. (POSSENTI, 2002, p.172)
\end{abstract}

A palavra star é estrangeirismo e a palavra estartar é empréstimo. Repare que esta última está modificada e segue as normas do português. Já foi enquadrada aos verbos da primeira conjugação: eu estarto/ eu estartei/ eu estartava/eu estartarei/ eu estartara/ eu tinha estartado, etc. Vejamos outros exemplos de empréstimos encontrados no dicionário de moçambicanismos. São palavras vindas de línguas moçambicanas na sua maioria:

Patchar: evocar espirito dos antepassados (provém de xichangana, ku patcha)

Tchovar: empurrar ( provém de xichangana ku tchova)

bula-bular: conversar (provém de xichangana; $k u$ bula)

guadjissar: roubar, furtar (provém de xichangana; ku guadjissa)

timbileiro: aquele que toca timbila (provém de xichangana; mbila é instrumento musical: xilofone (plural timbila)

Entendo por empréstimos, palavras que já foram estrangeirismos e que ao longo do tempo se solidificaram na língua e sofreram transformações a nível fonético ou ortográfico. Ao nosso ver, seriam aquelas palavras que por tanta necessidade de serem usadas por falantes de uma determinada língua, assimilaram-a na escrita e na fonética. Estas "novas" palavras quando chegam na língua alvo (neste caso, no português) incorporam e usam as regras gramaticais. Assim, a palavra tchova é estrangeirismo enquanto que tchovar é empréstimo pois assimilou as regras do português. Assim, diremos: eu tchovo, eu tchovei, eu tchoverei, eu tchovia e assim sucessivamente. Este é o português moçambicano. Este verbo não existe em nenhum outro país da CPLP.

\subsubsection{Razões da inserção de empréstimos e estrangeirismos numa língua}

Falando das causas dos empréstimos/estrangeirismos lexicais no Português de Moçambique, DIAS (1991), considera dois motivos fundamentais: empréstimos 
TIMBANE - Os estrangeirismos e os empréstimos...

lexicais como estratégias de comunicação e estrangeirismos lexicais como estratégias de identificação.

\section{a) Empréstimos lexicais como estratégias de comunicação}

Ocorrem quando os falantes recorrem aos termos da língua materna para preencherem lacunas na língua portuguesa de certas realidades, tipicamente moçambicanas, como por exemplo, nomes de frutos, flores, animais, comidas e certas cerimónias. De acordo com a autora, parece não haver muita preocupação por parte do falante, em procurar uma expressão equivalente em Português; nem sequer se preocupa em criar uma nova palavra que se ajuste ao sistema morfofonológico português.

Ainda na esteira de Dias, estes empréstimos ocorrem para preencherem lacunas no conhecimento da língua portuguesa, motivadas pelo fraco domínio da língua. Essa situação faz com que o falante não encontrando o item sintácticosemântico pretendido e tendo acesso ao léxico da língua materna, então, recorra ao empréstimo. Ainda de acordo com a autora que temos vindo a citar, "a outra estratégia alternativa usada nestes momentos de dificuldade é abortar a estrutura usando uma estratégia de evitação."

Este tipo de empréstimo é característico de qualquer aprendente de uma segunda língua ou língua estrangeira, podendo ocorrer tanto em crianças como em adultos (uma vez que tais empréstimos, regra geral, pertencem à interlinguagem, e são susceptíveis de substituição à medida que o aprendente progride na aprendizagem da nova língua.

\section{b) Estrangeirismos lexicais como estratégias de identificação}

Os falantes bilingues (Português / Línguas Moçambicanas) no uso da língua portuguesa utilizam estrangeirismos das suas línguas maternas. Esta situação tem a ver com o facto de a língua portuguesa ser oficial e ser a mais prestigiada na sociedade relativamente às línguas moçambicanas. Esta situação parece provocar no falante bilingue uma vontade subconsciente de unir os dois códigos. Ele não se sente bem na situação de prestigiar uma língua europeia em detrimento da sua região, dos seus avós, dos seus pais enfim, da sua cultura e identidade. Vejamos dois exemplos:

Exemplo 1: Khanimambo pela vossa presença.

"Obrigada pela vossa presença"

Exemplo 2: O próximo espectáculo será mahala

"O próximo espectáculo será gratuito"

"Khanimambo" e "mahana" são palavras vindas da língua xichangana.

APELL (1996, p.247) apresenta seis determinantes sociais e culturais que originam os empréstimos/estrangeirismos: 
a) Influência cultural, isto é, empréstimos culturais que surgem não do contacto de línguas distintas num mesmo espaço, mas sim de intercâmbios culturais.

b) Existência de palavras nativas raras que se perdem.

c) Existência de duas palavras nativas que se pronunciam ou soam de forma tão similar que a substituição de uma delas por uma palavra estrangeira resolveria possíveis ambiguidades.

d) Necessidade constante de sinónimos de palavras afectivas que perderam a sua força expressiva.

e) Necessidade de estabelecer novas distinções semânticas por meio de empréstimos, como por exemplo, a possibilidade de tomar uma palavra de uma língua de estatuto baixo e usá-la pejorativamente.

f) Introdução de palavras emprestadas de forma quase inconsciente por causa de um bilinguismo intenso, que faz com que, nalguns casos, seja usado na escrita sem a marca de estrangeirismo.

VILELA(1994), relativamente às causas que originam empréstimos/ estrangeirismos, refere-se a três situações que se manifestam no uso da língua e que implicam, quase forçosamente, o uso de empréstimos:

- a urgência em serem satisfeitas as necessidades de comunicação e expressão dos falantes;

- a exigência em configurar o que de novo surge na comunidade;

- a necessidade em manter a sistematicidade da língua.

Às razões apontadas por estes dois autores (VILELA, APELL, 1994, 1996), podemos ainda acrescentar duas motivações:

- A primeira, tem a ver com o prestígio de que goza a língua " $\mathrm{A}$ " em relação à língua nativa do falante. Motivada pelo prestígio, uma palavra será utilizada, como empréstimo, da língua A pela língua "B", não porque a palavra emprestada tenha falta de equivalente na língua "B", mas porque os falantes de "B" consideram A como tendo maior estatuto e prestígio.

- A segunda, prende-se com a necessidade de manifestar a solidariedade social entre pessoas de classes sociais diferentes como forma de identidade entre ambas as classes.

Face a esta diversidade de funções, os empréstimos são designados de formas diferentes tendo em conta a sua origem, função assim como a forma como se integram na nova língua.

\subsubsection{Estrangeirismos quanto à sua função: necessários e de luxo}

De acordo com VILELA (1994), os empréstimos necessários configuram conceitos a que não corresponde qualquer palavra existente na língua e designam 
TIMBANE - Os estrangeirismos e os empréstimos...

objectos desconhecidos na língua, ou melhor, são palavras que designam realidades não nomeadas num estado anterior da língua. O mesmo acontece com os estrangeirismos. As comunidades necessitam constantemente de receber estrangeirismos, pois elas não se bastam a si próprias, não dão conta das necessidades comunicativas da comunidade, uma vez que estão constantemente em intercâmbio/contacto com outras comunidades.

(a) jazz: música moderna de origem negro-americana caracterizada pelo improviso e pelas sonoridades e ritmos sincopados, basicamente extraídos do ragtime e do blues.

(b) miss: primeira colocada num concurso que elege a jovem mais bonita de um lugar ou a que obteve a preferência da maioria dos julgadores, com relação a outras qualidades

(c) doping: substância química que se dá a um cavalo para estimular o se desempenho; substância química que se ministra ilicitamente a um atleta, afim de alterar-lhe por momentos o condicionamento físico, aumento-lhe a resistência e o desempenho muscular.

No português moçambicano, por exemplo, há muitos estrangeirismos necessários, principalmente vindos das línguas bantu:

(d) Gwaza-muthini: ritual comemorações efectuadas em fevereiro, que marcam a abertura da época de canhu ${ }^{5}$ e recordam a batalha ganha aos portugueses durante a época da colonização.

(e) Kwassa-kwassa: dança originária da República Democrática de Congo, caracterizada por ser sensual e exigir mais esforço na cintura.

(f) Xiguinha: tipo de prato feito a base de mandioca, cacana e amendoim; prato característico no sul de Moçambique.

(g) Xigovia: tipo de instrumento musical feito a partir de fruto de massala ou de ncuácuá. Massala é uma planta silvestre que dá frutos redondos, cheios de sementes muito duras e que quando maduras ficam com cor amarela.

(h) Tchuva: jogo praticado com pedras em pequenas covas feitas no chão.

VILELA (1994), considera empréstimos/estrangeirismos de luxo, aqueles que recobrem conteúdos para os quais a língua importadora possui termos para referir tais realidades. Mas, apesar de existirem na língua unidades lexicais para referir tais conceitos, os falantes optam, normalmente, por termos estrangeiros pelo prestígio que a língua importadora possui.

Nota-se também que os falantes, na sua maioria, recorrem muitas vezes aos empréstimos do inglês pelo prestígio que esta língua goza - a língua inglesa

\footnotetext{
${ }^{5}$ Fruto de uma planta de porte médio (nkanyi) do qual se faz uma bebida tradicional (ucanyi) bebido gratuitamente em várias etnias do sul de Moçambique. A época do consumo desta bebida é geralmente inaugurado pelas autoridades locais, acompanhado de bebdida e danças tradicionais. É considerado património gastronómico e cultural moçambicano. Canhu é empréstimos de "ucanyi".
} 
funciona como língua franca em quase todo o mundo. Vejamos alguns exemplos deste fenómeno:

(a) file / ficheiro (b) marketing / comercialização (c) fashion / moda (d) e-mail/ correio electrónico (e) show/ espectáculo (musical, humorístico) (f) AIDS (acquired immunodeficiency syndrome)/ SIDA (síndrome da imunodeficiência adquirida).

\subsubsection{Integração de "novas " palavras na língua}

A integração dos estrangeirismos na nova língua pode ser feita por três vias ou processos: decalque, adaptação, incorporação.

a) Decalques ou empréstimos semânticos - trata-se de um empréstimo meramente conceptual que consiste na mudança semântica de uma palavra, de uma dada língua por influência de uma palavra estrangeira cujo significado adquire. Estes surgem quando a uma palavra existente se acrescenta um sentido novo, embora esta conserve o sentido anterior.

Por exemplo, a palavra chapa no Português brasileiro significa "qualquer peça plana, mais ou menos espessa, feita e material rígido ou resistente (metal, madeira, vidro, etc.); lamina, placa; licenciamento do veículo ${ }^{6}$." Mas actualmente, este mesmo vocábulo significa "remendo que se coloca na roupa; veículo automóvel para transporte semi-colectivo de passageiros".?

b) Adaptações ou empréstimos lexicais- os empréstimos adaptam-se à língua receptora que quase não percebemos que vieram de uma outra língua. Aqui o elemento lexical é traduzido literalmente, produzindo um novo sintagma que, de início, causa estranheza porque possivelmente não se formasse assim na língua, não fosse a imitação do empréstimo.

- O léxico proveniente das línguas bantu':

(1) kanganhiçar: fazer confusão; aldrabar.

(2) magussarinho: planta trepadeira que dá o magussarinho; legume comestível de forma alongada com interior esponjoso.

(3) timbileiro: aquele que toca timbila

- Adaptações provenientes do inglês:

(4) futebol (football)

(5) bipar (beep)

(6) deletar (delete)

\footnotetext{
${ }^{6}$ Dicionário electrónico HOUAISS DA LÍNGUA PORTUGUESA 3.0.

${ }^{7}$ Cf Dias,2002, p.82.

${ }^{8}$ Palavras consultadas no Minidicionário de moçambicanismos.
} 


\title{
2. NOÇÃO DE MOÇAMBICANISMOS E DEBATES RECENTES
}

Segundo DIAS (2002, p.20) denomina-se de moçambicanismos "todas as palavras (neologismos, empréstimos) que são mais tipicamente usadas em Moçambique e que mostram e particularizam a regionalização léxico-semântica do português em Moçambique." A definição de Dias é incompleta pois ao nosso ver, deve-se acrescentar os estrangeirismos. Essas palavras, resultam do contacto que o português tem/teve com as línguas africanas ao longo da colonização e pósindependência.

As condições sociais, culturais, o nível de escolaridade são algumas das variáveis que comparticipam neste comportamento linguístico. Partindo do princípio de que a língua muda com o tempo, é importante mostrarmos que as mudanças sempre ocorrem em primeira instancia a nível lexical. Estudos sociolinguísticos mostram que a gramática é a última a ser afectada pela variação. Moçambicanismos são

\begin{abstract}
indícios claros de afirmação de norma própria: na maneira original como adopta o seu vocabulário de origem bantu ao sistema português divergindo inclusivamente da norma européia (lusitana), no modo como simplifica a morfologia flexional do português, como começa a optar pela ordenação dos elementos frásicos na sequência discursiva e, sobretudo, como força o léxico do português a adaptar-se à mentalidade africana, tanto nos semas inerentes como semas classemáticos: o que implica, por vezes, uma reformulação do esquema frásico em alguns dos seus modelos proposicionais. (VILELA, 1995, p. 68)
\end{abstract}

Os moçambicanismos tem características próprias, específicas que criam uma diferença notável a nível fonético, semântico, lexical e morfo-sintático. As línguas naturais constituem configurações que mudam lentamente, moldadas pelo curso invisível e impessoal que é a vida da língua. Este fenómeno que pressupõe apropriação, recriação e enriquecimento da língua portuguesa por falantes moçambicanos, adaptando-a ao seu contexto sócio-cultural, segundo DIAS (2002), constitui a Moçambicanização da língua. Em Moçambique, os linguistas se dividem em duas opiniões distintas, segundo DIAS (2009b, p.390):

\footnotetext{
Opinião 1: Um grupo que defende a oficialização imediata das mudanças em curso e adopção de uma língua portuguesa moçambicana nos órgãos oficiais, na escola e nos meios de comunicação de massas. Este grupo é, muitas vezes, movido por sentimentos de nacionalismo, lealdade, orgulho e emancipação linguística.

Opinião 2: Outro grupo que afirma não existir uma língua portuguesa moçambicana e que há apenas uma variedade moçambicana em formação, pois não existem dados suficientes que permitem padronização de uma variedade moçambicana da língua portuguesa. Tais estudiosos defendem que as diferenças linguísticas, sincronicamente observáveis, não constituem verdadeiras mudanças linguísticas, pois estão sujeitas a muita variação e flutuação.
}

Se o português falado actualmente não foi o mesmo falado nos séculos passados em Portugal, porquê o de Moçambique deve permanecer estático, imutável e sólido? Apoiamos primeira opinião, pois as mudanças nunca avisam 
nem alertam aos seus falantes. Estamos falando do "O dinamismo das línguas". "As mudanças se processam de forma gradual em várias dimensões, de forma silenciosa, atacando a parte lexical, passando pelo fonético, morfosintático até ao semântico. (NARO, 2004, p.43)

Para Naro, "a mudança linguística não é absolutamente mecânica regular a curto prazo." É por isso, os que apoiam a $2^{\mathrm{a}}$ opinião não se apercebem destas mudanças de que nos referimos: as variáveis sociais (idade, sexo, nível de escolaridade, grupo social) e as variáveis linguísticas. Cidadãos movidos pelo espírito de identidade, de afirmação e defesa ao bem comum, que é a língua têm recusado a existência de moçambicanismos. Várias críticas relacionadas aos estrangeirismos têm aparecido um pouco por todo lugar, principalmente nos meios de comunicação social. Leonel Magaia, jornalista do Jornal "Notícias" reage às mudanças linguísticas dizendo:

\begin{abstract}
Os efeitos da globalização são aterradores. Sobretudo numa sociedade como a nossa, que não tem criadas estratégias de filtragem, o chamado efeito peneira, dos efeitos nefastos e perniciosos, preferindo-os aos socialmente benéficos e sadios. Vai daí que temos uma sociedade a caminhar célere para a desestruturação, que se reflecte na evidente falta de identidade dos moçambicanos. Infelizmente, importamos construções alheias e forçamos a sua incorporação na nossa sociedade. Entendemos que o melhor vem de fora. Abrimos um boteco qualquer de venda de bugigangas e damos-lhe o pomposo nome de souvernir's place.
\end{abstract}

Magaia recusa qualquer tipo de estrangeirismo no português falado em Moçambique, considerando uma "britanização" desnecessária. Para Magaia estes "estrangeirices" empobrecem a língua, leva-nos para uma aculturação que provoca efeitos nefastos sobretudo na desestruturação linguística e de identidade dos moçambicanos. A preocupação que o Magaia tem com a língua faz com que ele considera que há uma "fossilização do léxico nacional" pois algumas vezes este léxico tem sido usado em textos administrativos e protocolares.

Ora, a preocupação do Magaia é equiparada ao do Deputado Aldo Rebelo, no que toca ao projecto de lei 1.676/99. Achamos que as línguas não podem ser controladas por meio de leis. Ninguém foi preso, julgado e condenado por ter pronunciado/escrito um estrangeirismos sequer. Vale apenas mostrar o artigo 4. que diz o seguinte: "Todo e qualquer uso de palavra ou expressão e língua estrangeira, ressalvados os casos excepcionados nesta lei a sua regulamentação, será considerado lesivo ao património cultural brasileiro, punível na forma da lei”. Concluindo o debate, é importante saber que a língua não é pertence individual. É do colectivo. Quem incorpora "as novas palavras" é o povo. Não é vontade de individualidades. Assim, mesmo que fiquemos tristes com mudanças linguísticas, mesmo se promulgamos as leis defensoras não adiantará em nada. Esses fenómenos linguísticos atendem as necessidades comunicativas dos falantes (usuários).

9 http://www.jornalnoticias.co.mz/pls/notimz2/getxml/pt/contentx/1170815/20110127 Acesso aos 14 de maio 2011. 
TIMBANE - Os estrangeirismos e os empréstimos...

\section{CORPUS}

Em todo mundo, a mídia tem desempenhado um papel importante na difusão e expansão da língua. No mundo agitado e globalizado é quase impossível se abster dos serviços prestados pela mídia. Segundo NEVES (2003, p.519), mídia "designa o conjunto de meios de comunicação. É uma forma portuguesa correspondente ao inglês (mass) media, que por sua vez, representa o plural neutro do substantivo latino medium, que significa meio." No entanto, constituem mídias o jornal, a rádio, a televisão, a internet, a revista entre outras formas de comunicação.

A mídia moçambicana não fica alheia a estas mudanças. Muitas vezes, a inclusão de estrangeirismos tem como objetivo aproximar o leitor à sua realidade. Em outros casos é a inexistência do equivalente em português. Outras vezes ainda é por questão de estilo. Estas todas caraterísticas podem ser observadas em todos mídias sem exceção.

O corpus para este trabalho foi recolhido no "jornal Notícias", o maior jornal público em Moçambique. Foram selecionadas 27 cartas de Opinião em 2010-2011. As cartas selecionadas são de cidadãos de ambos os sexos, com nível de escolaridade básico completo. Todas as cartas foram escritas em português e selecionadas na página (site) do jornal. Os temas tratados nas cartas são variados, desde temas da política, da economia, da cultura, saúde entre outros. Assim, os textos foram preparados e inseridos (formato txt) no programa léxico-3 do qual pudemos analisar a frequência do léxico. A nossa especial atenção está nos empréstimos e estrangeirismos no português.

\subsection{Apresentação e discussão dos dados}

\subsubsection{Os estrangeirismos vindos de inglês}

Para ilustrar, a intervenção dos estrangeirismos nos mídias moçambicanos, observemos a seguir, alguns exemplos recolhidos nas cartas de "opinião", do jornal "Notícias" em 2010 e 2011:

... modista ou estilista e muito menos uma "expert" nesta matéria, por... (6/4/2010)

.. dai uma Renamo com um novo look (aparentemente), caracterizado ...(25/4/2010)

... meus compatriotas, aos pronunciamentos do mister Artur Semedo que... (25/4/2010)

... imprensa como um instrumento de marketing como se cura fosse um... $(29 / 6 / 2011)$

... na África do Sul, outra combatente contra o “apartheid”....(29/6/2011)

... Issa Hayatou, boss da CAF e vice da FIFA, recebeu 100 mil francos ...(24/6/2011)

... pelos transportadores de 15 lugares, vulgo "ten years" que, movidos... (3/1/2011)

....é um grande habitat de mosquitos causador da malária, devido a...(14/10/2010)

... Estrada Nacional $n^{\circ}$ 1, na zona do "Drive-In", não foi por falta de ... $(18 / 10 / 2010)$ 
Cadernos de ESTUDOS LINGüísTICOS (54.2) - Jul./Dez. 2012

... no interior do banco ou o sistema on-line do Barclays é deficiente ... (14/9/2010)

... um quilómetro numa mina na África do sul, para ver "in loco" como...(5/7/2010)

... que é o medo de as pessoas se encontrarem com os “ninjas”...(14/5/2010)

...dinheiro à prazo para servir-lhe de background. Assim, afirmamos ...(13/1/ 2011)

... regional do poder do regime do "apartheid”, que, graças às...(11/4/2011)

... as constantes subiidas no "ranking" sobre o respeito aos direitos ...(7/3/2011)

... a género do movimento beligerante eo modus operandis dos mesmos ... $(7 / 3 / 2011)$

... imediatos sem que antes resolvamos o eterno deficit de qualidade...(31/03/2011)

\subsubsection{Os estrangeirismos vindos de changana}

... incluindo claro os "txova-xitaduma”, provocam, não.. (10/4/2010)

... A esteira, o xiphefo e o fósforo. Estão no mesmo local e depois...(11/1/2011)

... optam por circular com "tchova" contendo banana, tomate,...(12/07/2010)

... pelo homem branco para o xibalo, considerando-os vadios...(28/3/2011)

....musa de msiro na cara e mulala nos lábios, cuja beleza outra igual.... $(30 / 5 / 2011)$

... queria dirigir com o meu "axifeni” (parabéns) que tanto mereces!...(16/7/2011)

... o protestantismo. Valoriza-o. Até conheço "maziones" que te admiram... $(16 / 7 / 2011)$

... e académica sobre a arte de governar um povo massinguita....(26/7/2011)

... fundo da mesa ao lado dizendo " Cuidado com os nhamakakatas"... (1/6/2011)

....nacional de futebol, os "Mambas", Mart Noiij desmentiu publicamente.... $(15 / 6 / 2011)$

Os exemplos que acabamos de apresentar, demostram a inserção dos estrangeirismos nos mídias moçambicanos. Este não só acontece nas "cartas de opinião". Muitos jornalistas estão cientes deste fenómeno linguístico e é por isso que sempre colacam essas palavras entre aspas. As palavras destacadas em 3.1.1. e 3.1.2. provém de estrangeirmos empréstimos vindos do inglês e do xichangana. Nas cartas encontramos estrangeirismos vindos de várias línguas mas centralizamos nossa pesquisa naqueles que vem do inglês e do xichangana. As palavras "Mambas" e "maziones" são empréstimos. Ocorreu a transformação das palavras $\operatorname{mamba}^{10}$ (plural timamba) e muzione ${ }^{11}$ (plural mazione). Para adaptação na língua portuguesa aplicou-se o singular(mamba), acrescentando o -s que é a marca de plurarl para muitos substantivos em português.

Na segunda palavra mazione é plural e assim, se transformou para português tendo sido acrescido o plural -s, características de muitos substântivos na língua

${ }^{10}$ Cobra muito venenosa que ocorre em África, que tem a capacidade de imitar sons de animais tais como: galinha, cabrito.

${ }^{11}$ Indivíduo que professa a religião zion. 
TIMBANE - Os estrangeirismos e os empréstimos...

portuguesa. Este comportamento é frenquente na passagem de estrangeirismos para empréstimos no português moçambicano.

a) O meu pai levou malassas.

b) Os timbilas tocam demais.

c) Ontem vimos palapalas na floresta.

d) Esses tchovas impedem a passagem.

Os estrangeirismos vindos de inglês, também são sujeitos às regras do português. Mas em muitos casos há dificuldades na transformação para plural. vejamos os casos de:

ten-years é "um combatente de luta armada de libertação nacional”. Mas também é "uma espécie de rato muito pequeno, difícil de ser eliminado e que se reproduz com muita facilidade.” (DIAS, 2002, p.223). esta palavra se mantém intacta e não tem alteração no singular e no plural. Concluímos que esta palavra se mantém estrangeirismo.

teacher, por exemplo, não é transformada para o plural.

Exemplo: O meu teacher na veio. Plural: Os meus teacher não vieram.

slow dança de ritmo suave, executada aos pares abraçados, ao som de música romântica, (DIAS, 2002, p.216).

Exemplo: O slow é a minha música preferida. Plural: Os slow são nos animam.

Off: cansado, estafado, saturado (DIAS, 2002, p.188).

Exemplo: Hoje estou off. Plural: Hoje estamos off.

Concluímos que nas línguas bantu, facilmente se transformam para plural enquanto as que provém do inglês se mantém. Estes fenómenos ocorrem na fala dos dois sexos. A formação académica e a experiência profissional faz com que cada falante tenha seus léxicos específicos. Os estrangeirismos teacher, slow, off ocorrem em percentagem maior nos jovens enquanto que ten-years ocorreu mais em pessoas de ligadas a política.

\section{CONSIDERAÇÕES FINAIS}

Os estrangeirismos e empréstimos são fenómenos linguísticos frequentes em todas as línguas. Moçambique sendo um país multilingue não pode estar isento aos contactos linguísticos provenientes de várias línguas, como vimos ao longo do trabalho. São estrangeirismos vindos das línguas bantu e também de línguas europeias na grande maioria. Os estrangeirismos variam de lugar para o outro, de cultura para cultura sem excessão. Uma vez que a língua sempre apresenta uma carga cultural isso se manifesta através do valor semântico que cada uma das têm no seu meio.

Em Moçambique, nunca falamos português tal como se fala em Lisboa. O Brasil, por sua vez, nunca falou português tal como se fala em Angola e por aí em diante. A língua é a mesma mas os contextos sociais e culturais fazem com que haja 
esta diversidade linguística. A questão de estrangeirismos é motivo de discussão na opinião pública e política. Alguns desavisados se acham capazes de controlar os destinos naturais das línguas. Das leituras feitas a propósito do fenómeno "variação e mudanças linguísticas", concluimos que este, é um fenómeno que está longe do controlo humano.

Neste trabalho discutimos conceitos de estrangeirismos e empréstimos na nossa visão e tentamos enquadrá-los no contexto do português moçambicano. $\mathrm{O}$ português moçambicano é uma realidade linguística real. Pesquisas feitas na área de variação linguística e mudança demonstraram que as mudanças nunca param desde que hajam falantes.

As línguas bantu nunca tiveram estatuto de língua oficial. Sempre foram abnegadas pela política linguística. Mas mesmo assim, elas se manifestam na língua portuguesa através do processo de empréstimos e estrangeirismos. O fenómeno de mudanças através de estrangeirismos é ditado pela convivência entre pessoas de diferentes culturas, pessoas de diferentes nações, falantes de diferentes línguas. O Brasil, Moçambique e muitos outros países plurilingues são compostas por diferentes etnias (culturas), vários povos que se misturam num determinado espaço geográfico, originando mistura entre línguas.

O avanço tecnológico através da internet, rádio e televisão sobretudo, têm dado maior espaço para que haja interacção entre pessoas. A língua inglesa parece ganhar mais espaço na arena mundial. As línguas mudam e sempre mudarão. As palavras estrangeiras podem mudar ortograficamente, outras vão se manter mas mudando a sua fonética, o importante é que tenhamos a língua como um instrumento de comunicação e de livre expressão. Para terminar, gostaríamos de tranquilizar à todos os que pensam que a língua se deteriora com empréstimos e estrangeirismos, dizendo o seguinte:

Não há dúvida de que a língua de civilização que nos serve é o português. Além do mais, ela não está nem um pouco em perigo de perder essa posição privilegiada: apesar do que se fala dos progressos do inglês em certas áreas, o português continua firme como o veículo de todos os aspectos da cultura brasileira. (PERINI, 2003, p. 33)

\section{$\overline{\text { REFERÊNCIAS BIBLIOGRÁFICAS }}$}

APPEL, R.; MUYSKEN, P. (1996). Bilinguismo y Contacto de Lenguas. Barcelona: Ariel Linguística.

BONVINI, E. (2004). Línguas africanas e português falado no Brasil. in FIORIN, J. L.; PETTER, M. (ors). África no Brasil: A formação da língua portuguesa. São Paulo: Contexto.

DIAS, H. N. (2009). A norma padrão e as mudanças linguísticas na língua portuguesa nos meios de comunicação de massas em Moçambique. In DIAS, H. N. (org). Português moçambicano: Estudos e reflexões. Maputo: imprensa universitária.

. (2002). Minidicionário de moçambicanismos. Maputo: Imprensa Universitária.

. (1991). Os empréstimos lexicais das línguas bantu no português. in: Actas do Simpósio Nacional sobre língua portuguesa em Africa. Escola superior de Santarém. . (2009b). Português moçambicano: Estudos e reflexões. Maputo: Imprensa Universitária. 
TIMBANE - Os estrangeirismos e os empréstimos...

FREITAS, T.; RAMILO, M. C.; SOALHEIRO, E. (2005). O processo de interação dos estrangeirismos no português europeu. In MATEUS, M. H. M.; NASCIMENTO do, F. B. (orgs). A Língua Portuguesa em Mudança. Lisboa: Caminhos.

GARCEZ, P.; ZILLES, A. M. (2001). Estrangeirismos: desejos e ameaças. In FARACO, C. A. (org). Estrangeirismos: Guerras em torno da língua. São Paulo: Parábola.

GONSALVES, C. A. F.; FERREIRA, D.C.; CUNHA, J. M. De J. et al. (2011). O uso do estrangeirismo na lingua portuguesa. Lisboa: Revela Guilbert, L. La créativité lexicale. Paris: Larousse, 1975.

MATEUS, M. H.M. (2002). A face exposta da língua portuguesa. Lisboa: Imprensa nacional-Casa da moeda.

MOÇAMBIQUE. Constituição. (2004). Constituição da República de Moçambique. Maputo, Assembleia da República.

NARO, A. J. (2004). O dinamismo das línguas. In MOLLICA, M. C. ; BRAGA, M. L. (orgs). Introdução à sociolinguística: O tratamento da variação. São Paulo: Contexto.

NEVES, M. H.M. (2003). Guia de uso do português: confrontando regras e usos. São Paulo: UNESP.

PERINI, M. (2004). A língua do Brasil amanhã e outros mistérios. São Paulo: Parábola.

POSSENTI, S. (2002). A questão dos estrangeirismos. In FARACO, C. A. (org.). Estrangeirismos: Guerras em torno da língua. São Paulo: Parábola.

BRASIL. PROJETO DE LEI Nº 1676 de 1999.

RAJAGOPALAN, K. (2004). Línguas nacionais como bandeiras patrióticas, ou a linguística que nos deixou na mão: observando mais de perto o chauvinismo linguístico emergente no Brasil. in SILVA da, F. L.; RAJAGOPALAN, K.(orgs). A linguística que nos faz falhar: Investigação crítica. São Paulo: Parábola.

SEQUEIRA, F.J. M. (1962). Rol de estrangeirismos e respectivas correspondências em português de lei. Lisboa: Livraria popular de Francisco franco.

TIMBANE, A. A. (2009). A problemática do ensino da língua portuguesa na 1 classe num contexto sociolinguístico urbano. O caso da cidade de Maputo. 2009.109f. Dissertação (Mestrado em Linguística)- Faculdade de Letras e Literatura, Universidade Eduardo Mondlane, Maputo.

VILELA, M. (1994). Estudos de Lexicologia do Português. Coimbra, Almedina. . (1995). Ensino da língua portuguesa: Léxico, dicionário, gramática. Coimbra: Almedina.

ZAMPARONI, V. (2000). Monhés, Baneanes, Chinas e afro-maometanos: colonialismo e racismo em Lourenço Marques,Moçambique, 1890-1940. in Lusotopie, 191-222

http://www.jornalnoticias.co.mz/pls/notimz2/getxml/pt/contentx/1170815/20110127 Acesso aos 14 de maio 2011

http://pt.wikipedia.org/wiki/Chauvinismo acesso aos 13 de julho 2011

Dicionário de estrangeirismos da língua portuguesa: http://www.portaldalinguaportuguesa.org/?action =estrangeirismos\&act=list

http://www.folha.uol.com.br/

http://www.jornalnoticias.co.mz/ 